\title{
Cardicola langeli sp. n. (Digenea: Aporocotylidae) from heart of sheepshead, Archosargus probatocephalus (Actinopterygii: Sparidae) in the Gulf of Mexico, with an updated list of hosts, infection sites and localities for Cardicola spp.
}

\author{
Stephen A. Bullard
}

Aquatic Parasitology Laboratory, Department of Fisheries and Allied Aquacultures, College of Agriculture, Auburn University, 203 Swingle Hall, Auburn, Alabama 36849, USA

\begin{abstract}
Cardicola langeli n. sp. (Digenea: Aporocotylidae) infects the heart of sheepshead, Archosargus probatocephalus (Walbaum, 1792) (Perciformes: Sparidae) in the northern Gulf of Mexico off Horn Island (type locality), Mississippi, USA. The new species is described herein using light and scanning electron microscopy of adult specimens and can be most easily distinguished from the other 24 accepted species of Cardicola Short, 1953 by the combination of having (i) an ovovitelline duct that extends anteriad and that (ii) is posterior to the ootype, (iii) a male genital pore that is lateral to the oviducal seminal receptacle and (iv) a female genital pore lateral to the ootype. The new species is the only member of Cardicola so-far reported to have tegumental spines that are distally flattened and broad, rather than pointed. The new species generally resembles the two other species of Cardicola that infect sparids, i.e. Cardicola cardiocolum (Manter, 1947) (type species) from jolthead porgy, Calamus bajonado (Block et Schneider), in the Gulf of Mexico and Cardicola aurata Holzer, Montero, Repullés, Sitja-Bobadilla, Alvarez-Pellitero, Zarza et Raga, 2008, from gilthead seabream, Sparus aurata Linnaeus, in the Mediterranean Sea, by having a spheroid anterior sucker with concentric rows of minute spines anterior to the mouth and by having a similar general arrangement of the vitellarium, gonads and genitalia. However, it differs from them by having the combination of the aforementioned five features plus asymmetrical posterior caeca and a dextral posterior caecum that extends beyond the posterior margin of the ovary. Probable eggs of $C$. langeli $\mathrm{n}$. sp. that contain a ciliated miracidium infect gill epithelium and are spheroid. An updated list of hosts, infection sites and geographic localities for the 25 accepted species of Cardicola is provided.
\end{abstract}

Keywords: fish blood fluke, taxonomy, 'Sanguinicolidae', vascular system, parasite

Adults of the accepted species of Cardicola Short, 1953 (Digenea: Aporocotylidae) infect the blood vascular system (principally the lumen of the heart) of marine and euryhaline bony fishes, with records now from most ocean basins (Table 1). Similar to that of Aporocotylidae, Cardicola has been the subject of extensive, recent taxonomic activity: 17 of its $24(71 \%)$ accepted species have been described since the year 2000. As a result, it is now the most species-rich marine aporocotylid genus; however, taxonomic revision subsequent to redescription of its type species [Cardicola cardiocolum (Manter, 1947) Short, 1953] may change that total (Bullard and Overstreet 2003, Bullard 2010a, McVay et al. 2011, Bullard et al. 2012). The genus includes what is probably now the most extensively-studied marine fish blood fluke: Cardicola forsteri Cribb, Daintith et Munday 2000, a blood fluke of true tunas (Thunnus spp., Scombridae) cultured in sea cages of South Australia and the Mediterranean Sea (Cribb et al. 2000, 2011, Colquitt et al. 2001, Bullard et al. 2004, Aiken et al. 2006, 2008, 2009, Hayward et al. 2007, 2008). Aside from this marquee aporocotylid most published work with Cardicola has focused on species discovery (Cribb and Bray 2011), and our knowledge of the general biology of most other species of Cardicola is lacking. Herein, I describe another new species of Cardicola based on specimens collected from the heart of sheepshead, Archosargus probatocephalus (Walbaum, 1792) (Perciformes: Sparidae) in Mississippi Sound, northern Gulf of Mexico.

\section{MATERIALS AND METHODS}

Sheepshead were captured on 9 July 2009 by baited hook and line. After capture, fish were maintained alive in aerated, ambient water or immediately killed by spinal severance, placed in a cooler with a small amount of ice and transported to the laboratory for necropsy. The heart of each fish was extracted, placed in a petri dish, immersed in physiologic saline, bisected to expose its lumen and examined with the aid of a dissecting 
microscope. Probable eggs of the new species were photographed embedded in gill epithelium by wet mounting clipped gill filaments on coverslipped glass slides.

Living specimens were pipetted onto a glass slide and heatkilled with an EtOH burner flame before being transferred to a vial of 5\% neutral buffered formalin, rinsed thoroughly with distilled water, stained overnight in Van Cleave's hematoxylin with several additional drops of Ehrlich's hematoxylin, made basic in $70 \%$ ethanol with lithium carbonate and butyl-amine, dehydrated, cleared in clove oil and permanently mounted in Canada balsam (Bullard and Overstreet 2004). The five specimens for scanning electron microscopy (SEM) were dehydrated, immersed in hexamethyldisilazane for $30 \mathrm{~min}$, air dried for $45 \mathrm{~min}$ and sputter-coated with $15 \mathrm{~nm}$ gold palladium. Illustrations of stained, whole-mounted specimens were made with the aid of a Leica DM-2500 equipped with differential interference contrast (DIC) optical components and a drawing tube. Measurements were obtained by using a calibrated ocular micrometre and are herein reported in micrometres $(\mu \mathrm{m})$ followed, in parentheses, first by the mean and then by the number of specimens measured for that feature. Common names for fishes follow Froese and Pauly (2012). Fish classification and nomenclature follow Nelson (2006). Nomenclature for Aporocotylidae follows Bullard et al. (2009). Specimens were deposited in the USNPC (holotype and a paratype) and IPCAS (a paratype).

\section{RESULTS}

\section{Cardicola langeli sp. n.}

Figs. 1-8

Diagnosis of adult (measurements and illustrations based on 12 whole-mounted adult specimens including the holotype, two paratypes and five sputter-coated specimens): Body flat, ventrally concave, elongate oval in shape, 1260-1720 (1485; $\mathrm{n}=7$ ) long, 280-400 (328; $7)$ or $4.1-4.8 \times$ longer than wide, having anterior and posterior ends equally rounded, lacking posterolateral body protuberance. Body-margin inconsistently crimped ventrally or straight depending on state of contraction when fixed, spined (Figs. 1-3).

Tegumental body spines minute, $2-3(2 ; 7)$ long, approximately $500 \mathrm{~nm}$ wide (Figs. 4, 5), near limits of light microscopy but best visualized with $100 \times$ oil immersion objective or SEM, not associating with pronounced tegumental peduncles or body protuberances, protruding from tegument approximately $700 \mathrm{~nm}$, in transverse rows (Figs. 4, 5). Tegumental spine rows distributing along ventrolateral body surface for entire body length from mouth to extreme posterior body end, distributing in approximately 260-383 $(309 ; 5)$ rows each spaced $5(5 ; 7)$ apart per side of body or a total of 520-766 $(616 ; 5)$ rows, approximately $5(5 ; 7), 18-25(22 ; 5)$, and $8-13(10 ; 6)$ in breadth in anterior, middle and posterior portions of body, respectively, having $2-4(4 ; 7), 8-10(9 ; 7), 8-9(8 ; 7)$ spines per row in anterior, middle and posterior portions of body, respectively. Fused or rosethorn-shaped spines lacking.

Nervous system difficult to trace in most specimens, comprising at least a ventrolateral nerve cord plus associ- ated anterior commissures (Figs. 1-3). Ventrolateral nerve cords paired and extending posteriad in parallel with body margin, showing secondary branches extending laterad and mediad, 10-15 $(12 ; 6)$ wide near midbody at widest level, appearing widest in anterior region of body in some specimens and narrowing somewhat posteriorly, 43-50 $(48 ; 6)$ from body margin at midbody, contiguous at body ends, becoming confluent with paired cord in posterior body end (Fig. 1). Dorsolateral nerve cord not clearly evident but trace of its commissure evident at level midway between ventrolateral nerve commissure and anterior body end. Commissure of ventrolateral nerve cord 88 $138(112 ; 6)$ or $7-8 \%(8 \% ; 6)$ of body length from anterior body end, $38-50(45 ; 6)$ across width of worm, $8-15$ (11; 6 ) in diameter, perpendicular to long axis of body, coursing dorsal to oesophagus. Ventral and dorsal tegumental sensory papillae not evident with SEM.

Anterior sucker spinous, comprising a spheroid structure centring on mouth, 23-28 $(25 ; 6)$ long, 25-30 (28; 6) wide or $6-10 \%(9 \% ; 6)$ of body width, consistently wider than long, directing ventrally (Figs. 1-3). Anterior sucker spines distributing in concentric rows anterior to mouth, each spine $<1$ long, numbering approximately 80 in posteriormost row at equator of anterior sucker, decreasing in number as diameter of sucker lessens anteriorly. Mouth a minute pore, $3(3 ; 7)$ in diameter, medioventral, 12-14 $(13 ; 4)$ from anterior end (Figs. 2, 3).

Terminal preoral lobe not evident with light microscopy or SEM. Spines associated with oesophagus or mouth not evident with light microscopy or SEM. Pharynx absent. Oesophagus $415-650(497 ; 6)$ long or $29-38 \%$ of body length, $10-25(20 ; 7)$ wide, widest at level midway between nerve commissure and end of oesophagus, slightly sinuous in posterior portion but more or less straight anteriorly, widening slightly posteriorly before connecting with caecal bifurcation anteroventrally; oesophageal wall $3-8(5 ; 7)$ thick or $20-53 \%(28 \% ; 6)$ of oesophagus width (Fig. 1). Oesophageal gland extremely diffuse and difficult to distinguish from surrounding parenchyma in stained whole-mounted specimens, appearing to envelop oesophagus in middle portion of oesophagus midway between caecal intersection and ventrolateral nerve commissure, $225-250(238 ; 2)$ long or $41-60 \%(51 \% ; 2)$ of oesophagus length, concentrating in area approximately $25-100(60 ; 3)$ wide or $7-25 \%(17 \% ; 3)$ of body width, not clearly differentiated into anterior and posterior portions (Fig. 1).

Intestine $\mathrm{X}$ - or H-shaped, with paired anterior and posterior caeca intersecting medially (Fig. 1). Intersection of anterior and posterior caeca $415-650(522 ; 4)$ or $32-38 \%$ $(35 \% ; 4)$ of body length from anterior end. Anterior caeca equal or not equal in length, $75-138(93 ; 6)$ long or $5-9 \%$ $(6 \% ; 6)$ of body length, $16-19 \%(18 \% ; 6)$ of oesophagus length, $26-50(42 ; 6)$ wide or $9-18 \%(13 \% ; 6)$ of body width, not extending lateral to ventrolateral nerve cord, 
smooth, rounded anteriorly, lacking diverticula (Fig. 1). Posterior caeca not extensively convoluted but extending posteriad sinuously, with dextral caecum longer in all specimens studied. Dextral posterior caecum extending beyond posterior margin of ovary, 580-780 $(670 ; 6)$ long or $43-48 \%(45 \% ; 6)$ of body length, $6.4-10.3 \times(7.8 \times ; 6)$ length of anterior caeca, $13-25(17 ; 5)$ wide before expanding distally to $25-48(33 ; 5)$ or $1.8-2.3 \times(2.0 \times ; 5)$ its width before expanding; sinistral posterior caecum shorter in all specimens, extending to level of posterior margin of testis only, preovarian, 420-610 $(488 ; 6)$ long or $26-38 \%(33 \% ; 6)$ of body length, $57-81 \%(73 \% ; 6)$ of dextral posterior caecum length, $5.7-6.3 \times(6.0 \times ; 4)$ length of anterior caeca, $20-30(26 ; 5)$ wide before expanding distally to $25-38(33 ; 4)$ or $0.8-1.9 \times(1.3 \times ; 4)$ its width before expanding (Fig. 1).

Genitalia mostly delimited laterally by ventrolateral nerve cord (Figs. 1, 7, 8). Testis having irregular margins, poorly staining in most specimens, lateral lobes present in some specimens, $350-550(440 ; 6)$ long or $27-34 \%(30 \%$; 6) of body length, $150-210(178 ; 6)$ in maximum width or $40-62 \%(55 \% ; 6)$ of body width at level of posterior $1 / 3$ of body, $2.2-3.4 \times(2.5 \times ; 6)$ wider than long, extending laterad beyond limits of posterior caeca and in some specimens slightly lateral to ventrolateral nerve cord, not extending anteriad to level of caecal intersection; posttesticular space $370-530(442 ; 6)$ long or $28-32 \%(30 \%$; 6) of body length, accommodating male and female reproductive tracts.

Vasa efferentia difficult to trace in fixed specimens, an interconnecting meshwork of fine ducts entwining throughout testicular tissue, containing spermatozoa, extending primarily along ventral surface of testis, uniting in posterior region of testis to form vas deferens; vas deferens 175-225 (198; 4) long, 10-25 (16; 3) wide at level of ovary, extending posteriad from posterior margin of testis, passing ventral to and in sinistral portion of ovary, curving mediad and crossing midline before curving and directing sinistrally, extremely thin-walled, containing sperm in all specimens, $8-13(10 ; 4)$ wide before connecting with seminal vesicle (Figs. 7, 8). Seminal vesicle oblong, 50-125 (84; 6) long, 10-30 (16; 6) wide or 4.2-6.8× $(5.5 \times ; 6)$ longer than wide, orienting diagonally posteriad or nearly transverse. Gland surrounding seminal vesicle indistinct. Everted cirrus small, nipple-like, unarmed, ap-

Fig. 1. Cardicola langeli sp. n. from heart of sheepshead, Archosargus probatocephalus in the northern Gulf of Mexico (holotype, USNPC No. 106126). Abbreviations: ac - anterior caecum; as - sucker; dc - dorsolateral nerve commissure; dpc - dextral posterior caecum; fp - female genital pore; $\mathrm{mp}$ - male genital pore; o - ovary; oe - oesophagus; og - oesophageal gland; oo - ootype; pc - posterior caecum; spc - sinistral posterior caecum; $\mathrm{t}$ - testis; $\mathrm{tsr}$ - transverse spine rows; ut - uterus; $\mathrm{v}$ - vitelline follicles; vc - ventrolateral nerve commissure; ve - vasa efferentia; vt - primary vitelline duct. Ventral view. Scale bar $=500 \mu \mathrm{m}$.

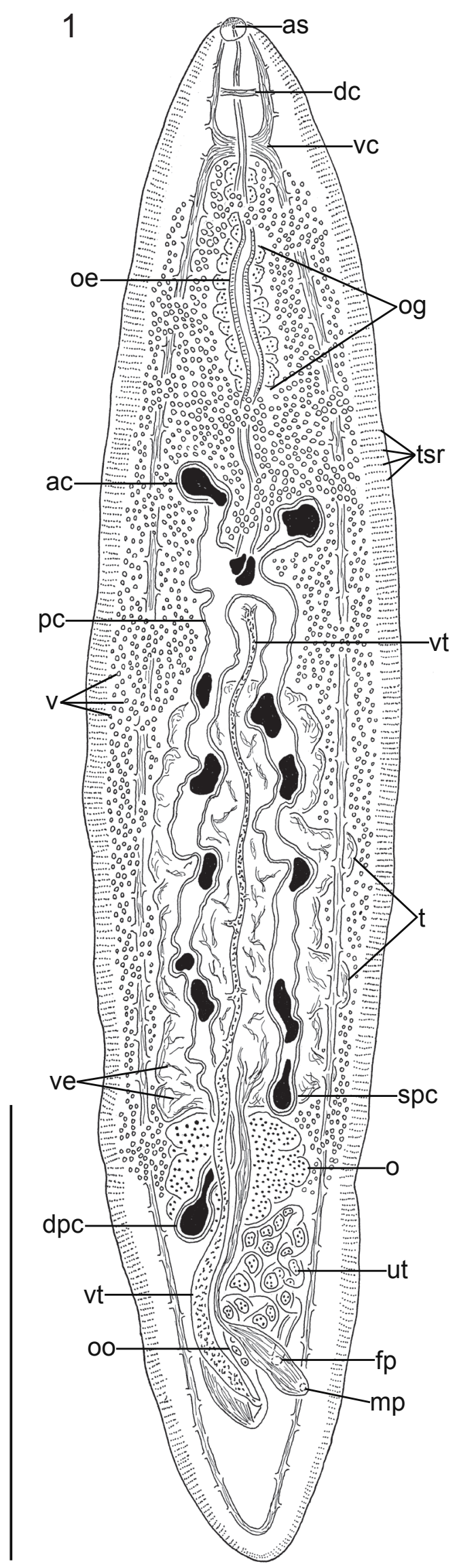



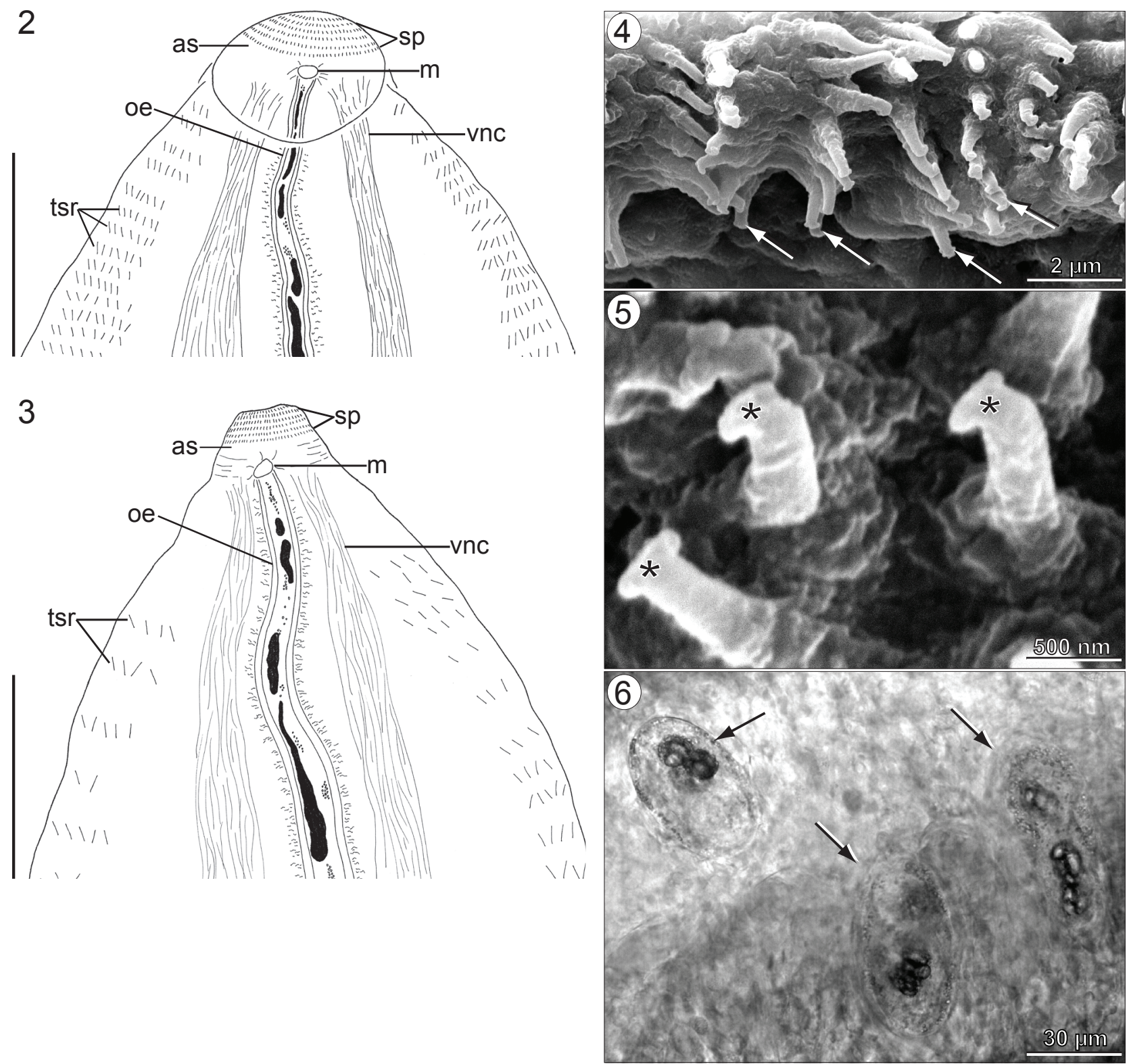

Figs. 2-6. Cardicola langeli sp. n. from heart of sheepshead, Archosargus probatocephalus, in the northern Gulf of Mexico. Fig. 2. Anterior end of adult specimen showing spines ( $\mathrm{sp}$ ) of anterior sucker (as) arranged in concentric rows anterior to the mouth (m) as well as the anterior portion of the oesophagus (oe), ventrolateral nerve cord (vnc) and transverse spine rows (tsr). Ventral view. Scale $b a r=40 \mu \mathrm{m}$. Fig. 3. Anterior end of juvenile specimen showing comparable features as in Fig. 2. Note that the anterior sucker is less spheroid and resembles a proboscis-like structure (cf. penetration organ of the cercaria of Cardicola forsteri Cribb, Daintith et Munday, 2000 - see Cribb et al. 2011). Ventral view. Scale bar $=40 \mu \mathrm{m}$. Fig. 4. Tegumental spine rows (arrows). Fig. 5. High magnification view of three spines $(*)$ depicted in Fig. 4. Note that tips of spines appear flattened and broad, rather than sharply pointed. Scanning electron micrographs. Fig. 6. Eggs (arrowheads) embedded in epithelium. Light microscopy of wet-mounted live specimens.

proximately 8 long and 5 wide, everting dorsally at level of sinistral ventrolateral nerve cord.

Ovary not strongly dendritic or branched, lacking deep lobes, having small lateral lobes (Figs. 7, 8), 80-163 $(118 ; 6)$ long or $6-9 \%(8 \% ; 5)$ of body length, $150-200$ $(174 ; 7)$ wide or $38-67 \%(53 \% ; 5)$ of body width, $1.1-$ $1.9 \times(1.5 \times ; 6)$ wider than long, medial, occupying space immediately posterior to testis, dorsal to vas deferens, not extending laterad beyond ventrolateral nerve cords, with posterior margin of ovary being straight across breadth of body or having slightly pointed end extending posteriad before connecting with oviduct (Figs. 1, 7, 8). Postovarian space $305-390(337 ; 6)$ long or $20-25 \%(23 \% ; 6)$ of body length (Fig. 1). Oviduct extending 75-113 (96; 6) directly posteriad from posteromedial margin of ovary, straight (Fig. 7) or slightly convoluted (Fig. 8), 5-8 (6; 6) 
wide, connecting with oviducal seminal receptacle well posterior to ovary and at level approximately equal to that of junction of vas deferens and seminal vesicle. Oviducal seminal receptacle comprising distal portion of oviduct, $88-145(123 ; 6)$ long, $23-48(34 ; 6)$ wide or $2.5-6.3 \times$ longer than wide, extending posteriad in parallel with and medial to ventrolateral nerve cord, residing at level of male genital pore, narrowing posteriorly before curving sharply dorsally, giving rise to a short duct that extends anteriad a short distance before joining with vitelline duct, filled with sperm in all specimens, primarily posterior to level of genitalia and gonads (Figs. 7, 8).

Vitellarium follicular, distributing from level of ventrolateral nerve commissure posteriad to posterior margin of ovary, symmetrical (lacking dextral or sinistral extensions), extending lateral to ventrolateral nerve cords along length (Fig. 1); secondary collecting ducts indistinct; common collecting duct medial, a sinuous duct extending posteriad at least from level of caecal intersection before passing ventral to ovary and lateral to oviducal seminal receptacle, extending ventrally along track of oviduct and medial to vas deferens before uniting with oviduct and forming ovovitelline duct (Fig. 1). Ovovitelline duct 23-25 $(24 ; 6)$ long, $5(5 ; 6)$ wide, extending anteriad a short distance before connecting with ootype (Figs. 7 , $8)$. Ootype $50-55(53 ; 2)$ long, 20-25 $(23 ; 2)$ wide, oblong, directing slightly mediad, wholly anterior to level of junction of oviduct and vitelline duct, at level of or slightly anterior to male and female genital pores; postootype distance $133-198(162 ; 5)$ or $10-13 \%(11 \% ; 5)$ of body length (Figs. 7, 8).

Uterus extending anteriad from ootype, highly convoluted for entire length, comprising ascending and descending portions (Figs. 7, 8). Ascending uterus extending anteriad in a straight line distance (not including all turns of duct) $138-213(162 ; 5)$ or $9-13 \%(11 \%$; 6) of body length, $30-48(34 ; 4)$ in maximum width, primarily occupying space between ootype and ovary as well as space immediately lateral to vas deferens, continuing anteriad and reaching level of distal tip of dextral posterior caecum, post-testicular, primarily postovarian (Figs. 7, 8). Transition from ascending to descending uterus slightly sinistral to posterior margin of ovary or abutting posterior margin of ovary. Descending uterus a convoluted tube connecting with metraterm, $113-138(125 ; 2)$ long or $75-81 \%(78 \%$; $2)$ of ascending uterus length, $18-25(22 ; 2)$ in maximum width, connecting with proximal portion of metraterm immediately anterior to, or at level of, oviducal seminal receptacle and ootype (Figs. 7, 8). Metraterm 50-63 (57; 2) long, 36-40 $(38 ; 2)$ wide, occupying space between ascending uterus and ventrolateral nerve cord, with wall 4-8 $(6 ; 2)$ thick, directing mediad and crisscrossing (dorsal to) with seminal vesicle (Figs. 7,8). Uterine eggs seemingly amassed in irregularly-shaped clusters 20-25 $(23 ; 3)$ in diameter, filling uterus lumen (Figs. 7, 8). Female genital pore dorsal, sinistral, postovarian, anteromedial to male genital pore, dorsal to seminal vesicle (Fig. 7) or slightly lateral to it (Fig. 8), 158-238 $(185 ; 5)$ or $10-14 \%(12 \%$; 5 ) from posterior body end (Figs. 1, 7, 8). Excretory system indistinct in fixed, whole-mounted specimens.

Probable eggs infecting gill epithelium, spheroid (not spindle-shaped as in Cardicola laruei Short, 1953 - see McVay et al. 2011), lacking polar extensions, containing ciliated miracidium (Fig. 6).

Type and only host: Sheepshead, Archosargus probatocephalus Walbaum, 1792 (Perciformes: Sparidae).

Typ e 1 o c a lity: Off Horn Island ( $\left.30^{\circ} 15^{\prime} 18^{\prime \prime} \mathrm{N} ; 88^{\circ} 35^{\prime} 28^{\prime \prime} \mathrm{W}\right)$, Mississippi, Mississippi Sound, Northern Gulf of Mexico, USA.

Site in host: Lumen of heart.

Prevalence of infection: Twelve of 16 (75\%) sheepshead had 1-4 flukes each (mean intensity 1.4).

Specimens deposited: Holotype and one paratype in the United States National Parasite Collection (USNPC No. $106126=$ USNPC holotype, $106127=$ USNPC paratype); one paratype in the Institute of Parasitology, Academy of Sciences of the Czech Republic, České Budějovice (IPCAS D-692).

E t y molog y: The specific epithet langeli honours my former ichthyology student Christopher Adam Langel (Kaukauna, Wisconsin, USA; 8 April 1986-10 March 2012) for his inspiring 'beginner's mind' about the sea and its biology.

Remarks. Cardicola langeli sp. n. can be most easily distinguished from its congeners (Table 1) by the combination of having (i) an ovovitelline duct that extends anteriad (Figs. 1, 7, 8) and that (ii) is posterior to the ootype (Figs. 7, 8), (iii) a male genital pore that is lateral to the oviducal seminal receptacle (Figs. 1, 7, 8) and (iv) a female genital pore that is lateral to the ootype (Figs. 7, 8). All species of Cardicola except C. langeli; $C$. cardiocolum (Manter, 1947) Short, 1953 (type species); C. whitteni Manter, 1954; C. forsteri Cribb, Daintith et Munday, 2000; C. palmeri Bullard et Overstreet, 2004; C. aurata Holzer, Montero, Repullés, Sitjà-Bobadilla, Alvarez-Pellitero, Zarza et Raga, 2008; and C. opisthorchis Ogawa, Ishimaru, Shirakashi, Takami et Grabner, 2011 have an ovovitelline duct that is anterior to the ootype and that extends posteriad, rather than anteriad, from the junction of the oviduct and vitelline duct.

Among the species of Cardicola having an ovovitelline duct in that orientation, only the new species and $C$. whitteni possess a male genital pore that is lateral to the oviducal seminal receptacle. The remaining aforementioned species have a male genital pore that is markedly posterior to the level of the oviducal seminal receptacle. Cardicola langeli has a female pore that is dorsolateral to the ootype but that of $C$. whitteni is far anterior to the level of the ootype. The new species somewhat, but not uncannily, resembles $C$. cardiocolum and C. aurata, i.e. the other species of Cardicola infecting porgies (Sparidae), by having a spheroid anterior sucker with concentric rows of minute spines anterior to the mouth and by having a similar general arrangement of the vitellarium, gonads and genitalia. 
7

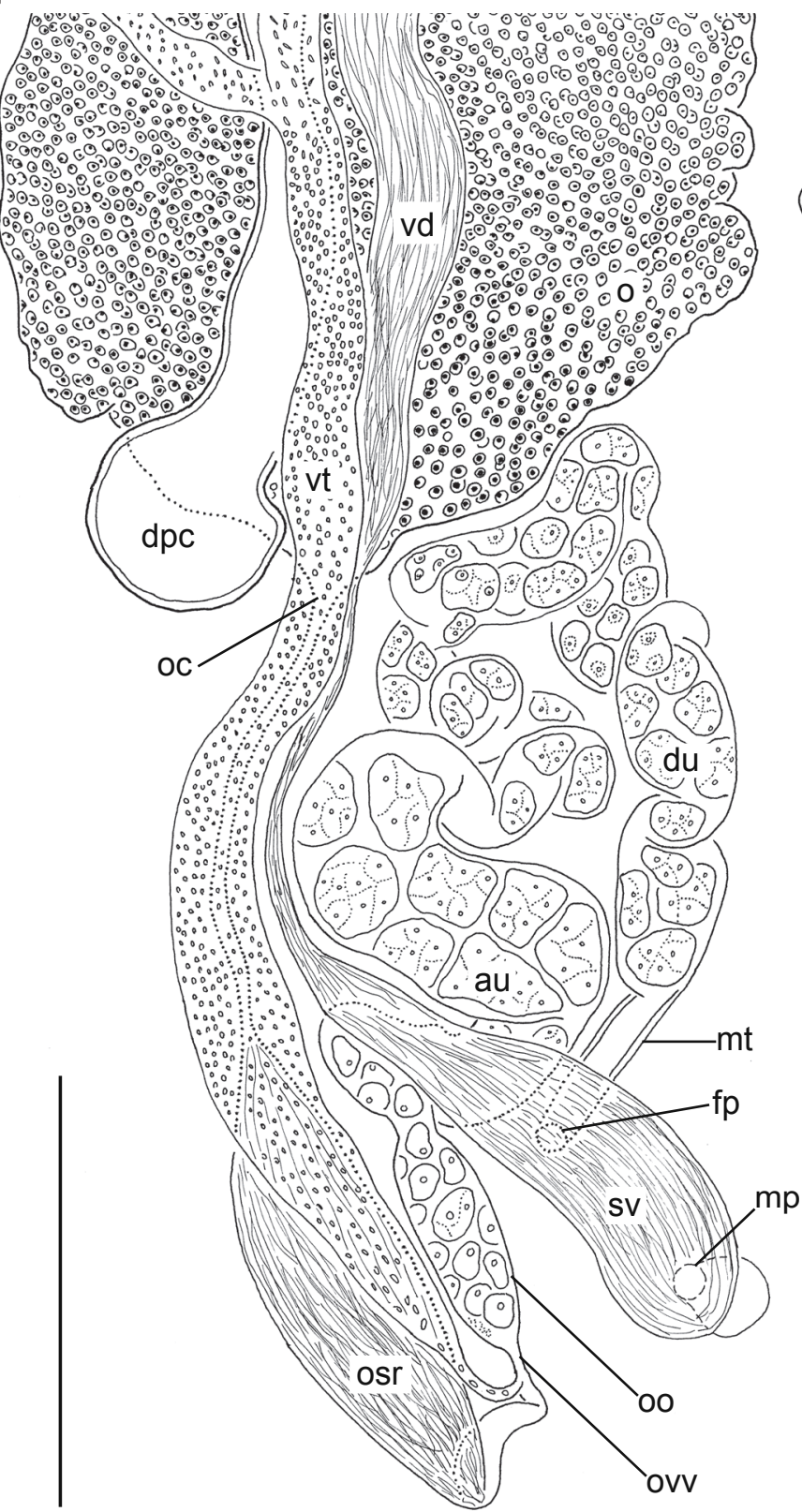

8

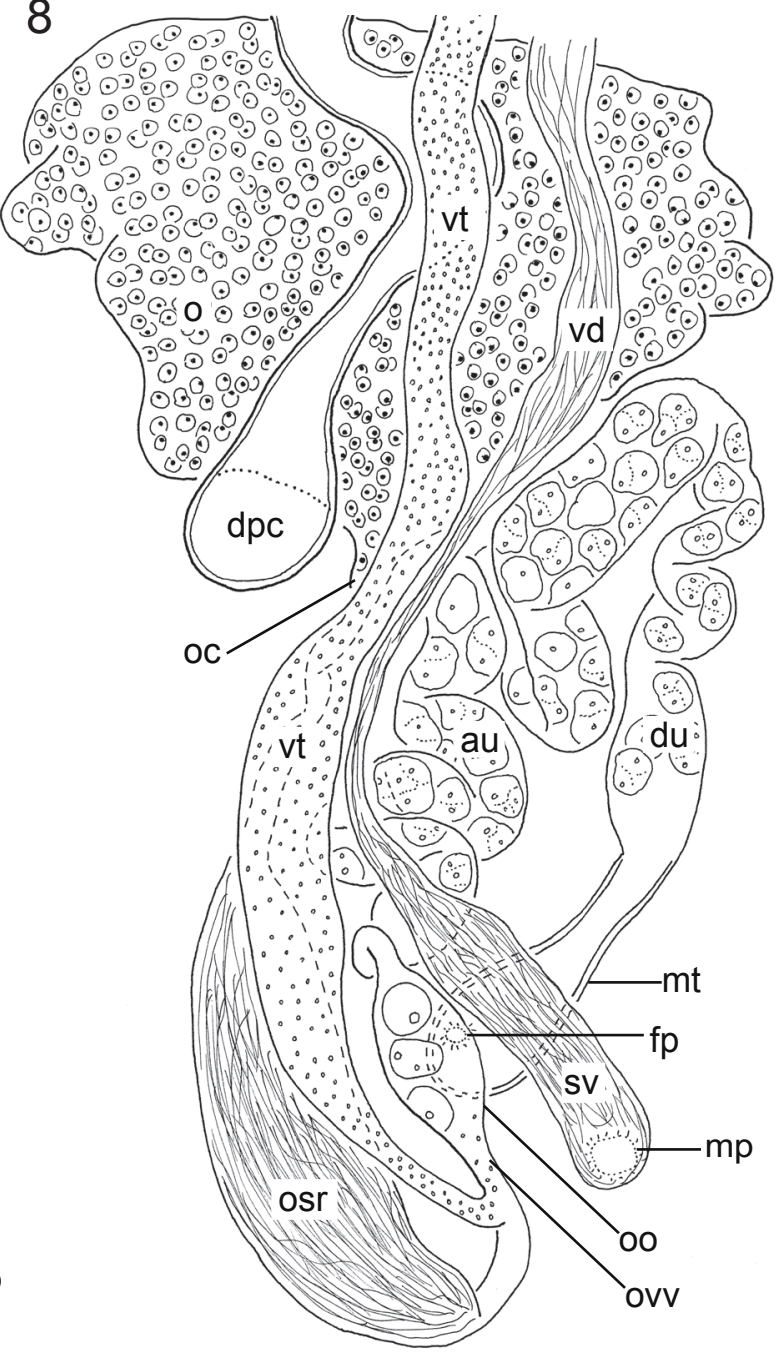

Figs. 7, 8. Cardicola langeli sp. n. from heart of sheepshead, Archosargus probatocephalus, in the northern Gulf of Mexico. Fig. 7. Genitalia (holotype, USNPC No. 106126). Abbreviations: au - ascending uterus; dpc - distal posterior caecum; du - descending uterus; $\mathrm{fp}$ - female genital pore; $\mathrm{mp}$ - male genital pore; $\mathrm{mt}$ - metraterm; o - ovary; oc - oviduct connection with ovary; oo - ootype; osr - oviducal seminal receptacle; ovv - ovovitelline duct; sv - seminal vesicle; vd - vas deferens; vt - vitelline duct. Ventral view. Scale bar $=100 \mu \mathrm{m}$. Fig. 8. Genitalia (paratype USNPC No. 106127) showing comparable features as illustrated in Fig. 7. Ventral view at same scale as Fig. 7.

However, the new species is most easily differentiated from C. cardiocolum and C. aurata at least by having the aforementioned combination of four diagnostic features plus asymmetrical posterior caeca, including a long dextral posterior caecum that extends beyond the posterior margin of the ovary.

The literature holds no example of an aporocotylid having flattened, broad tips of the lateral tegumental spines as were observed in C. langeli. Ultrastructure study can be timely, expensive and logistically prohibitive, so this feature is likely not altogether practical for the taxonomy of aporocotylids, and certainly it is probable that other described aporocotylid species have unique spines that simply have not been described in adequate detail. However, these spines, being minute and at the limit of resolution for light microscopy, do not appear different from those of other aporocotylids having tegumental spines with distally recurved, sharply pointed tips unless viewed with SEM. 


\section{DISCUSSION}

The presence/absence of, and morphological features related to, the sucker associated with the mouth of aporocotylids is probably best informed by the study of conspecific cercaria, juveniles and adults, but this is seldom possible and most species are described from adults only. This has been discussed fairly extensively (Bullard and Overstreet 2003, Nolan and Cribb 2006, Bullard et al. 2008, 2012, Bullard 2010a, b, 2012, McVay et al. 2011) and it is thought that juveniles or small adults of a given species can have a sucker whereas larger adults can lack that sucker. For example, McVay et al. (2011) showed that the holotype of $C$. laruei lacks an evident sucker but that newly-collected materials comprising smaller adult specimens had a spinous anterior sucker with concentric rows of spines anterior to the mouth. The same seems true for small and large adult specimens of Cardicola parvus Bullard, Baker et de Buron, 2012 (Bullard, personal observations). Regarding observations of the sucker in cercaria of Cardicola spp., the only cercaria that has been illustrated is that of $C$. forsteri.

Cribb et al. (2011) treated this type of sucker (oral sucker) as a specialized penetration organ, and that structure strongly resembles the thimble-shaped, spinous sucker (Fig. 3) we observed in a specimen of $C$. langeli that measured $1260 \mu \mathrm{m}$ in length and $280 \mu \mathrm{m}$ in width. In adult specimens of $C$. langeli the sucker apparently becomes spheroid, directed ventrally and with posterior constrictions where it connects with the body (Fig. 2). Conversely, despite being present in the cercaria of $C$. forsteri, the sucker is absent in the adult of $C$. forsteri (see Cribb et al. 2000) and in the adults of at least a few other species of Cardicola, e.g. C. currani and C. nonamo Bullard, 2010 (see Bullard and Overstreet 2004, Bullard 2010a). These results together reinforce the notion that adults of some species of Cardicola 'lose' the sucker and that in others it may be retained but paedomorphic and homologous to the penetration organ.

Egg morphology might be underutilized as a means of differentiating species of Cardicola and aporocotylid genera. The egg for the vast majority of aporocotylid species has not been described, but that for several members of Cardicola has been well-documented from both wild and aquacultured fishes wherein intense infections of eggs in the gill can be associated with disease (see Bullard and Overstreet 2002, 2004, 2008, Braicovich et al. 2006, Holzer et al. 2008, Ogawa et al. 2010, McVay et al. 2011). Shirakashi et al. (2012) used ITS2 sequence data to ascribe 'crescent' eggs infecting the afferent filament artery and 'oval' eggs infecting the gill lamellae of Pacific bluefin tuna (Thunnus orientalis) to Cardicola opisthorchis and Cardicola orientalis, respectively.

Eggs presumed to be $C$. laruei from the gill of seatrouts (Cynoscion spp.) are spindle-shaped (McVay et al. 2011), even before a fully-developed, ciliated miracidium is evident within the egg. In contrast, C. langeli, C. currani,
C. aurata and C. ambrosioi reportedly each have an oval egg. The egg of no other species of Cardicola has been described to date, but future species descriptions that include details of the fully-developed egg could help elucidate if egg shape is principally the result of fluke ancestry or the site of infection in the host. Such details could also contribute to a revised generic diagnosis for Cardicola. Noteworthy in this regard, however, is that no data are available on the shape of the egg of $C$. cardiocolum (type species). It should also be noted that aporocotylid eggs undergo considerable ex-utero development and that morphologically dissimilar eggs may represent conspecific, different-aged eggs. Hence, eggs that contain fully-developed, ciliated miracidia should be used for interspecific comparisons whenever possible.

The present study brings the total number of species assigned to Cardicola to 25 (Table 1). The genus presently accommodates flukes that mature in the blood vascular system (none reported from body cavity) of 'higher bony fishes' (subdivision Euteleostei) (see Johnson and Patterson 1996, Nelson 2006). Among euteleosteans, Cardicola spp. infect mullets (Mugiliformes: Mugilidae) plus ten host families of Perciformes and thus, remarkably, no record of any nominal, accepted species of Cardicola exists from any fish species assigned to the remaining $26 \mathrm{eu}-$ teleostean orders. Of course, other blood fluke genera include species that infect those orders, but whether or not 'Cardicola' is a group containing perciform blood flukes plus a few atypical species that infect euryhaline fishes is not convincing. A few species, i.e. C. mugilis Yamaguti, 1970, C. brasiliensis Knoff et Amato, 1992, C. currani Bullard et Overstreet, 2004, C. palmeri and C. parvus, mature in euryhaline mugilids and drums (Sciaenidae), show strong associations with estuaries and may presumptively include freshwater-origin or brackish-water intermediate hosts. However, the vast majority of species assigned to Cardicola infect obligate, stenohaline marine euteleosteans. The life cycle of only $C$. forsteri has been determined with molecular markers (Cribb et al. 2011).

A total of 14 fish blood flukes currently assigned to nine genera are known to range in the Gulf of Mexico (Table 1; Linton 1910, McIntosh 1934, Short 1954, Bullard and Overstreet 2003, 2006, Bullard et al. 2006, Bullard and Jensen 2008, Bullard 2010b, 2012): Deontacylix ovalis Linton, 1910, Paradeontacylix sanguinicoloides McIntosh, 1934, C. cardiocolum, C. laruei, C. palmeri, C. currani, C. langeli, Elaphrobates euzeti Bullard et Overstreet, 2003, Psettarium anthicum Bullard et Overstreet, 2006, Selachohemecus olsoni Short, 1954, Selachohemecus benzi Bullard, Overstreet et Carlson, 2006, Myliobaticola richardheardi Bullard et Jensen, 2008, Littorellicola billhawkinsi Bullard, 2010 and Pearsonellum lemusi Bullard, 2012. The diversity of host lineages exploited by these flukes as well as the genus-level and species-level diversity of aporocotylids seemingly indicates that Gulf of Mexico fish blood flukes remain worthy of exploration 
Table 1. Records of adult infections of accepted nominal species of Cardicola Short, $1953^{1}$ in chronological order of species descriptions.

\begin{tabular}{|c|c|c|c|c|}
\hline & Host & Site(s) & Locality & Reference(s) \\
\hline $\begin{array}{l}\text { Cardicola cardiocolum } \\
\text { (Manter, 1947) Short, } \\
1953 \text { (type species) }\end{array}$ & $\begin{array}{l}\text { Calamus bajonado (Bloch et Schneider) } \\
\text { (Perciformes: Sparidae), } \\
\text { jolthead porgy (type host) }\end{array}$ & heart & $\begin{array}{l}\text { Gulf of Mexico, off Tortugas, Florida, } \\
\text { USA (type locality) }\end{array}$ & $\begin{array}{l}\text { Manter (1947), } \\
\text { Short (1953) }\end{array}$ \\
\hline
\end{tabular}

1953 (type species) jolthead porgy (type host)

(as Psettarium)

$\begin{array}{lll}\text { Cardicola laruei Short, Cynoscion arenarius Ginsburg } & \text { heart } \\ 1953 & \text { (Perciformes: Sciaenidae), }\end{array}$

(Perciformes: Sciaenidae)

hearthern Gulf of Mexico, off Franklin Short $(1952,1953)$

sand seatrout (type host)

and Wakulla Counties, Florida, USA

(type locality)

Eastern Gulf of Mexico, Tampa Bay, McVay et al. (2011)

Florida, USA

Cynoscion nebulosus (Cuvier) (Perciformes: Sciaenidae), spotted seatrout

'washings of Northern Gulf of Mexico, off Franklin Short (1953)

gut' and Wakulla Counties, Florida, USA

heart Eastern Gulf of Mexico, Tampa Bay, McVay et al. (2011)

heart $\quad$ Florida, USA

heart John's River Estuary, Florida, USA

McVay et al. (2011)

gill ${ }^{2} \quad$ Southwest Pacific Ocean, off Welling- Manter (1954) $\begin{array}{ll}\text { Cardicola coridodacis } & \text { Odax pullus (Forster) (Perciforme } \\ \text { Manter, } 1954 & \text { Odacidae), greenbone (type host) }\end{array}$

(as Coridodax pullus)

Cardicola whitten ciformes: Cheilodactylidae), tarakihi (type host) (as Dactylopagrus macropterus)

Cardicola chaetodontis Chaetodon miliaris Quoy et Gaimard Yamaguti, 1970 (Perciformes: Chaetodontidae) millet butterflyfish (type host)

Chaetodon aureofasciatus Macleay, golden butterflyfish

Chaetodon citrinellus Cuvier, speckled butterflyfish

Chaetodon flavirostris Günther,

black butterflyfish

Chaetodon lineolatus Cuvier, lined butterflyfish

Chaetodon reticulatus Cuvier, mailed butterflyfish

Chaetodon ulietensis Cuvier, Pacific double-saddle butterflyfish Chaetodon unimaculatus Bloch, teardrop butterflyfish

gill, heart

blood $^{3}$

blood $^{3}$

blood $^{3}$

blood $^{3}$

blood $^{3}$

blood $^{3}$

blood $^{3}$

Mugil cephalus Linnaeus

Cardicola mugilis

Yamaguti, 1970

(Mugiliformes: Mugilidae),

flathead mullet (type host)

Cardicola brasiliensis Mugil platanus Günther

Knoff et Amato, 1992 Brazil mullet (type host)

Cardicola forsteri Thunnus maccoyii (Castelnau)

Cribb, Daintith et Mun- (Perciformes: Scombridae), day, 2000 southern bluefin tuna (type host) Thunnus thynnus (Linnaeus), northern bluefin tuna
Cardicola palmeri Bull- Pogonias cromis (Linnaeus) ard et Overstreet, 2004 (Perciformes: Sciaenidae), black drum Cardicola currani Bull- Sciaenops ocellatus Linnaeus) ard et Overstreet, 2004 (Perciformes: Sciaenidae), red drum
Cardicola coeptus Nolan et Cribb, 2006

Cardicola covacinae Nolan et Cribb, 2006 Cardicola bartolii Nolan et Cribb, 2006
Siganus punctatus (Schneider et Forster) heart, gill

(Perciformes: Siganidae), gold-spotted spinefoot (type host)

Siganus vulpinus (Schlegel et Müller), foxface

Siganus punctatus (type host)

Siganus lineatus (Valenciennes), golden-lined spinefoot (type host)

Siganus corallinus (Valenciennes), blue-spotted spinefoot heart ton, New Zealand (type locality)

Southwest Pacific Ocean, off Welling- Manter (1954) ton, New Zealand (type locality)

Central Pacific Ocean, off Hawaii, Yamaguti (1970) USA (type locality)

Southwestern Pacific Ocean, Lizard Nolan and Cribb (2006) Island, Australia

Southwestern Pacific Ocean, Moorea, Nolan and Cribb (2006) French Polynesia

Southwestern Pacific Ocean, Heron Nolan and Cribb (2006)

Island, Australia

Southwestern Pacific Ocean, New Nolan and Cribb (2006) Caledonia

Southwestern Pacific Ocean, Moorea, Nolan and Cribb (2006) French Polynesia

Southwestern Pacific Ocean, Heron Nolan and Cribb (2006)

Island, Australia

Southwestern Pacific Ocean, Palau

Nolan and Cribb (2006)

Southwestern Pacific Ocean, Heron Island, Australia

heart, Central Pacific Ocean, off Hawaii, blood vessels USA (type locality)

heart, kidney, Southwestern Atlantic Ocean, off Rio Knoff and Amato liver, gill de Janeiro, Brazil (type locality)

heart Southwestern Pacific Ocean, off Rabbit Island (type locality) and Island, South Australia

heart Northwestern Atlantic Ocean, off Cape Bullard et al. (2004) Lookout, North Carolina, USA

heart Mediterranean Sea, Puerto de Mazarron, Spain

heart, kidney, Adriatic Sea, Island of Brač, Croatia gill $^{4}$

Northern Gulf of Mexico, Mississippi Sound, USA (type locality)

Northern Gulf of Mexico, Mississippi Sound, USA (type locality)

Southwestern Pacific Ocean, Heron Island, Australia (type locality)

heart, gill Southwestern Pacific Ocean, Heron Island, Australia

heart Southwestern Pacific Ocean, Heron Island, Australia (type locality)

heart, gill Southwestern Pacific Ocean, Heron Island, Australia (type locality)

heart, gill Southwestern Pacific Ocean, Heron Island, Australia
Aiken et al. (2007)

Mladineo and Tudor (2004) (2004)

Bullard and Overstreet (2004), see also Overstreet (1983)

Nolan and Cribb (2006)

Nolan and Cribb (2006)

Nolan and Cribb (2006)

Nolan and Cribb (2006)

Nolan and Cribb (2006)
Bullard and Overstreet 
Table 1. Continued.

\begin{tabular}{|c|c|c|c|c|}
\hline & Host & Site(s) & Locality & Reference(s) \\
\hline $\begin{array}{l}\text { Cardicola watsonensis } \\
\text { Nolan et Cribb, } 2006\end{array}$ & Siganus corallinus (type host) & heart & $\begin{array}{l}\text { Southwestern Pacific Ocean, Lizard } \\
\text { Island, Australia (type locality) }\end{array}$ & Nolan and Cribb (2006) \\
\hline $\begin{array}{l}\text { Cardicola lafii Nolan et } \\
\text { Cribb, } 2006\end{array}$ & $\begin{array}{l}\text { Siganus fuscescens (Houttuyn), } \\
\text { mottled spinefoot (type host) }\end{array}$ & heart & $\begin{array}{l}\text { Southwestern Pacific Ocean, Lizard } \\
\text { Island, Australia (type locality) }\end{array}$ & Nolan and Cribb (2006) \\
\hline $\begin{array}{l}\text { Cardicola milleri Nolan } \\
\text { et Cribb, } 2006\end{array}$ & $\begin{array}{l}\text { Lutjanus bohar (Forsskål) } \\
\text { (Perciformes: Lutjanidae), } \\
\text { two-spot red snapper (type host) }\end{array}$ & heart & $\begin{array}{l}\text { Southwestern Pacific Ocean, Lizard } \\
\text { Island, Australia (type locality) }\end{array}$ & Nolan and Cribb (2006) \\
\hline $\begin{array}{l}\text { Cardicola parilus No- } \\
\text { lan et Cribb, } 2006\end{array}$ & Siganus fuscescens (type host) & heart & $\begin{array}{l}\text { Indian Ocean, Ningaloo Reef off } \\
\text { Western Australia (type locality) }\end{array}$ & Nolan and Cribb (2006) \\
\hline $\begin{array}{l}\text { Cardicola tantabiddii } \\
\text { Nolan et Cribb, } 2006\end{array}$ & Siganus fuscescens (type host) & heart & $\begin{array}{l}\text { Indian Ocean, Ningaloo Reef off } \\
\text { Western Australia (type locality) }\end{array}$ & Nolan and Cribb (2006) \\
\hline $\begin{array}{l}\text { Cardicola ambrosioi } \\
\text { Braicovich, Etchegoin, } \\
\text { Timi et Sardella, } 2006\end{array}$ & $\begin{array}{l}\text { Percophis brasiliensis Quoy et Gaimard } \\
\text { (Perciformes: Percophidae), } \\
\text { Brazilian flathead (type host) }\end{array}$ & liver, gill & $\begin{array}{l}\text { Southwestern Atlantic Ocean, off } \\
\text { Mar del Plata, Argentina (type locality) }\end{array}$ & Braicovich et al. (2006) \\
\hline $\begin{array}{l}\text { Cardicola aurata } \\
\text { Holzer, Montero, Re- } \\
\text { pullés, Sitjà-Bobadilla, }\end{array}$ & $\begin{array}{l}\text { Sparus aurata Linnaeus } \\
\text { (Perciformes: Sparidae), } \\
\text { gilthead seabream (type host) }\end{array}$ & gill & $\begin{array}{l}\text { Mediterranean Sea, off Valencia, } \\
\text { Spain (type locality) }\end{array}$ & Holzer et al. (2008) \\
\hline
\end{tabular}

pulles, Sitja-Bobadilla, gilthead seabream (type host)

Alvarez-Pellitero, Zarza

et Raga, 2008

Cardicola orientalis Thunnus orientalis (Temminck et Sch- gill

Ogawa, Tanaka, Sugi- legel) (Perciformes: Scombridae),

gill Western Pacific Ocean, off Japan

(type locality)

Ogawa et al. (2010)

hara et Takami, 2010 Pacific bluefin tuna (type host)

Cardicola nonamo Phanerodon furcatus Girard (Perciformes: heart

Bullard, $2010 \quad$ Embiotocidae), white seaperch (type host)

Rhacochilus toxotes Agassiz gill

Eastern Pacific Ocean, Monterey Bay, Bullard (2010a) California, USA (type locality)

Eastern Pacific Ocean, Naples Reef, Bullard (2010a) (Embiotocidae), rubberlip seaperch $\quad$ California, USA

Cardicola opisthor-

Thunnus orientalis (type host) heart

Western Pacific Ocean, off Japan (type locality)

Shirakashi, Takami et

Grabner, 2011

Cardicola parvus Bull- Micropogonias undulatus (Linnaeus) heart

ard, Baker et de Buron, (Perciformes: Sciaenidae),

$2012 \quad$ Atlantic croaker (type host)

Cardicola langeli $\mathrm{n}$. sp. Archosargus probatocephalus (Perci- heart formes: Sparidae), sheepshead (type host)

Northwestern Atlantic Ocean,

South Atlantic Bight (type locality)

Northern Gulf of Mexico, off Horn Island, USA (type locality)

${ }^{1}$ Bullard (2010a) treated Cardicola congruenta Lebedev et Mamaev, 1968, Cardicola grandis Lebedev et Mamaev, 1968 (see Lebedev and Mamaev 1968, Bullard and Overstreet 2006), Cardicola ahi Yamaguti, 1970 (see Yamaguti 1970) and Cardicola kurochkini (Parukhin, 1976) Bullard et Overstreet, 2006 (see Parukhin 1976) as species incertae sedis. ${ }^{2}$ Manter (1954) specified "gills and coelom probably from blood vessels". ${ }^{3}$ Nolan and Cribb (2006) reported heart, gill, and blood vessels of intestine. ${ }^{4}$ Eggs only, not adults.

and taxonomic discovery. For example, new aporocotylid species continue to be collected from commonly-occurring and easily-captured fishes in the Gulf of Mexico, e.g. C. langeli from sheepshead.

Although fish blood fluke genera seemingly include species that infect particular orders or related orders of definitive hosts, within a fish family congeneric aporocotylids, including Cardicola spp., do not seemingly show obvious morphological similarities. For example, the new species (C. langeli), C. cardiocolum and $C$. aurata all infect porgies (Sparidae) (Table 1); however, none is remarkably similar to another. Although in an unusual site of infection, Skoulekia meningialis Alama-Bermejo, Montero, Raga et Holzer, 2011 also infects a sparid and clearly does not belong within Cardicola: it has a posterolateral body protuberance (absent in Cardicola spp.) and a uterus that is lateral to the ovary and extends anterior to it (uterus is postovarian in Cardicola spp.) (Alma-Bermejo et al. 2011). Likewise, even congeneric, sympatric blood flukes that infect confamilial fishes are not obviously morphologically similar. For example, C. palmeri and $C$. currani infect sciaenids of Mississippi Sound (Bullard and Overstreet 2004) but, relative to other spe- cies of Cardicola, these flukes are not morphologically similar: C. palmeri has an ovoid body outline, anterior and posterior caeca that are sinuous and approximately equal in length, a large, transverse, seminal vesicle and large cirrus. In contrast, C. currani has an elongate body, long posterior caeca, short anterior caeca, a small seminal vesicle and tiny cirrus. Cardicola spp. that infect tunas (Thunnus spp.: Scombridae) provide another example (Cribb et al. 2000, Ogawa et al. 2010, 2011). Collectively, this morphological diversity is interesting regarding the natural history of aporocotylids, especially within Cardicola, since it may indicate a rapid rate of speciation within biodiverse vertebrate groups like Perciformes.

Acknowledgements. I thank Eric Hoberg and Pat Pilitt (both USNPC) for loaning materials and ensuring safe deposition of the types plus Michael Miller (Department of Biological Sciences, Auburn University Research Instrumentation Facility) and Carlos F. Ruiz (Aquatic Parasitology Laboratory, Auburn University) for helping obtain the SEM micrographs. This is a contribution of the Southeastern Cooperative Fish Parasite and Disease Project and was supported in part by National Science Foundation's Division of Environmental Biology grant numbers NSFDEB 1112729, NSF-DEB 1051106 and NSF-DEB 1048523. 
Aiken H.M., Bott N.J., Mladineo I., Montero F.E., Nowak B.F., Hayward C.J. 2007: Molecular evidence for cosmopolitan distribution of platyhelminth parasites of tunas (Thunnus spp.). Fish Fisheries 8: 167-180.

Aiken H.M., Hayward C., Cameron A., Nowak B. 2009: Simulating blood fluke, Cardicola forsteri, infection in farmed southern bluefin tuna, Thunnus maccoyii, using stochastic models. Aquaculture 293: 204-210.

Aiken H.M., Hayward C.J., Crosbie P., Watts M., Nowak B.F. 2008: Serological evidence of an antibody response in farmed southern bluefin tuna naturally infected with the blood fluke Cardicola forsteri. Fish Shellfish Immunol. 25: 66-75.

Aiken H.M., Hayward C.J., Nowak B.F. 2006: An epizootic and its decline of a blood fluke, Cardicola forsteri, in farmed southern bluefin tuna, Thunnus maccoyii. Aquaculture 254: 40-45.

Alama-Bermejo G., Montero F.E., Raga J.A., Holzer A.S. 2011: Skoulekia meningialis n. gen., n. sp. (Digenea: Aporocotylidae Odhner, 1912), a parasite surrounding the brain of the Mediterranean common two-banded seabream Diplodus vulgaris (Geoffroy Sain-Hilaire, 1817) (Teleostei: Sparidae): description, molecular phylogeny, habitat and pathology. Parasitol. Int. 60: 34-44.

Braicovich P.E., Etchegoin J.A., Timi J.T., Sardella N.H. 2006: A new species of Cardicola Short, 1953 (Digenea: Aporocotylidae) parasitizing the Brazilian flathead, Percophis brasiliensis Quoy et Gaimard 1824, from the coasts of Mar del Plata, Argentina. Parasitol. Int. 55: 175-177.

Bullard S.A. 2010a: A new species of Cardicola Short, 1953 (Digenea: Aporocotylidae) from the heart and branchial vessels of two surfperches (Perciformes: Embiotocidae) in the eastern Pacific Ocean off California. J. Parasitol. 96: 382-388.

Bullard S.A. 2010b: Littorellicola billhawkinsi n. gen., n. sp. (Digenea: Aporocotylidae) from the myocardial lacunae of Florida pompano, Trachinotus carolinus (Carangidae) in the Gulf of Mexico; with a comment on interrelationships and functional morphology of intertrabecular aporocotylids. Parasitol. Int. 59: 587-598.

Bullard S.A. 2012: Pearsonellum lemusi n. sp. (Digenea: Aporocotylidae) from blood vascular system of gag grouper, Mycteroperca microlepis (Perciformes: Serranidae) off Alabama, with an emendation of Pearsonellum Overstreet and Køie, 1989. J. Parasitol. 98: 323-327.

Bullard S.A., Baker T., de Buron I. 2012: New species of Cardicola (Digenea: Aporocotylidae) from heart of Atlantic croaker, Micropogonias undulatus (Perciformes: Sciaenidae), of the south Atlantic Bight. J. Parasitol. 98: 328-332.

Bullard S.A., Goodwin R., Goldstein R., Overstreet R.M. 2004: Cardicola forsteri (Digenea: Sanguinicolidae) from the heart of a northern bluefin tuna, Thunnus thynnus (Scombridae), in the Northwest Atlantic Ocean. Comp. Parasitol. 71: 245-246.

Bullard S.A., Jensen K. 2008: Blood flukes (Digenea: Aporocotylidae) of stingrays (Myliobatiformes: Dasyatidae): Orchispirium heterovitellatum from Himantura imbricata in the Bay of Bengal and a new genus and species from Dasyatis sabina in the Northern Gulf of Mexico. J. Parasitol. 94: 1311-1321.

Bullard S.A., Jensen K., Overstreet R.M. 2009: Historical account of the two family-group names in use for the single accepted family comprising the "fish blood flukes." Acta Parasitol. 54: 78-84.
Bullard S.A., Overstreet R.M. 2002: Potential pathological effects of blood flukes (Digenea: Sanguinicolidae) on pen-reared marine fishes. Ann. Proc. Gulf Caribb. Fish. Inst. 53: 10-25.

Bullard S.A., Overstreet R.M. 2003: Elaphrobates euzeti gen. and sp. n. (Digenea: Sanguinicolidae) from snappers (Lutjanidae) in the Gulf of Mexico. In: C. Combes and J. Jourdane (Eds.), Taxonomie, Écologie et Évolution des Métazoaires Parasites. Livre hommage à Louis Euzet. Tome 1. PUP, Perpignan, pp. 97-113.

Bullard S.A., Overstreet R.M. 2004: Two new species of Cardicola Short, 1952 (Digenea: Sanguinicolidae) from the heart of drums (Sciaenidae) in the Northern Gulf of Mexico. J. Parasitol. 90: 128-136.

Bullard S.A., Overstreet R.M. 2006: Psettarium anthicum sp. n. (Digenea: Sanguinicolidae) from the heart of cobia Rachycentron canadum (Rachycentridae) in the Northern Gulf of Mexico. Folia Parasitol. 53: 117-124.

Bullard S.A., Overstreet, R.M. 2008: Digeneans as Enemies of Fishes. In: J. Eiras, H. Segner, T. Wahil and B.G. Kapoor (Eds.), Fish Diseases, Vol. 2. Science Publishers, Enfield, New Hampshire, pp. 817-976.

Bullard S.A., Overstreet R.M., Carlson J.K. 2006: Selachohemecus benzi n. sp. (Digenea: Sanguinicolidae) from the blacktip shark Carcharhinus limbatus in the Northern Gulf of Mexico. Syst. Parasitol. 63: 143-154.

Bullard S.A., Snyder S.D., Jensen K., Overstreet R.M. 2008: New genus and species of Aporocotylidae (Digenea) from a lower actinopterygian, the American paddlefish, Polyodon spathula, (Polyodontidae) from the Mississippi Delta. J. Parasitol. 94: 487-495.

Colquit S.E., Munday B.L., Daintith M. 2001: Pathological findings in southern bluefin tuna, Thunnus maccoyii (Castelnau), infected with Cardicola forsteri (Cribb, Daintith \& Munday, 2000) (Digenea: Sanguinicolidae), a blood fluke. J. Fish Dis. 24: 225-229.

Cribb T.H., Adlard R.D., Hayward C.J., Bott N.J., Ellis D., Evans D., Nowak B.F. 2011: The life cycle of Cardicola forsteri (Trematoda: Aporocotylidae), a pathogen of ranched southern bluefin tuna, Thunnus maccoyii. Int. J. Parasitol 41: 861-870.

Cribb T.H., Bray R.A. 2011: Trematode families and genera: have we found them all? Trends Parasitol. 27: 149-154.

Cribb T.H., Daintith M., Munday B. 2000: A new blood-fluke, Cardicola forsteri (Digenea: Sanguinicolidae) of southern blue-fin tuna (Thunnus maccoyii) in aquaculture. Trans. R. Soc. S. Aust. 124: $117-120$.

Froese R., Pauly E. (Eds.) 2012: FishBase. World Wide Web electronic publication, www.fishbase.org, version 08/2012.

Hayward C.J., Aiken H.M., Nowak B.F. 2007: Metazoan parasites on gills of southern bluefin tuna (Thunnus maccoyii) do not rapidly proliferate after transfer to sea cages. Aquaculture 262: 10-16.

Hayward C.J., Aiken H.M., Nowak B.F. 2008: Epizootics of metazoan gill parasites did not threaten feasibility of farming southern bluefin tuna (Thunnus maccoyii) in a trail extending over summer months. Vet. Parasitol. 154: 122-128.

Holzer A.S., Montero F.E., Repullés A., Nolan M.J., SitjaBobadilla A., Alvarez-Pellitero P., Zarza C., Raga J.A. 2008: Cardicola aurata sp. n. (Digenea: Sanguinicolidae) from Mediterranean Sparus aurata L. (Teleostei: Sparidae) and its 
unexpected phylogenetic relationship with Paradeontacylix McIntosh, 1934. Parasitol. Int. 57: 472-482.

Johnson G.D., Patterson C. 1996: Relationships of lower euteleostean fishes. In: M.L. Stiassny, L.R. Parenti and G.D. Johnson (Eds.), Interrelationships of Fishes. Academic Press, San Diego, pp. 251-332.

Knoff M., Аmato J.F.R. 1992: Nova espécie do gênero Cardicola Short, 1953 (Sanguinicolidae: Cardicolinae) parasita de tainhas Mugil platanus Günther, 1880 da costa do estado do Rio de Janeiro, Brasil. Rev. Bras. Biol. 51: 567-570.

Lebedev V.I., Mamaev Yu.L. 1968: [Two new species of Cardicola Short, 1953 (Trematoda: Sanguinicolidae) from fish in the South China Sea.] In: K.I. Skryabin and Yu.L. Mamaev (Eds.), Helminths of Animals of the Pacific Ocean. Izdat. Nauka, Moscow, pp. 72-75. (In Russian.)

Linton E. 1910: Helminth fauna of the Dry Tortugas. II. Trematodes. Carnegie Institution Washington 133: 11-98.

Manter H.W. 1947: The digenetic trematodes of marine fishes of Tortugas, Florida. Am. Midl. Nat. 38: 257-416.

Manter H.W. 1954: Some digenetic trematodes from fishes of New Zealand. Trans. R. Soc. N. Z. 82: 475-568.

McIntosh A. 1934: A new blood trematode, Paradeontacylix sanguinicoloides n. g., n. sp., from Seriola lalandi with a key to the species of the family Aporocotylidae. Parasitology 26: 463-467.

McVay M.J., Bakenhaster M.D., Bullard S.A. 2011: Cardicola laruei Short, 1953 (Digenea: Aporocotylidae) from heart of seatrouts, Cynoscion spp. (Perciformes: Sciaenidae) in the Gulf of Mexico and Atlantic Ocean: taxonomic redescription, first observations of egg and miracidium, and comments on geographic distribution and host specificity. Comp. Parasitol. 78: 291-305.

Mladineo I., Tudor M. 2004: Digenea of Adriatic cage-reared Northern bluefin tuna (Thunnus thynnus thynnus). Bull. Eur. Assoc. Fish Pathol. 24: 145-152.
Nelson J.S. 2006: Fishes of the World, Fourth Edition. John Wiley and Sons, Inc., New York, 601 pp.

Nolan M.J., Cribb T.H. 2006: Cardicola Short, 1953 and Braya n. gen. (Digenea: Sanguinicolidae) from five families of tropical Indo-Pacific fishes. Zootaxa 1265: 1-80.

Ogawa K., Ishimaru K., Shirakashi S., Takami I., Grabner, D. 2011: Cardicola opisthorchis n. sp. (Trematoda: Aporocotylidae) from the Pacific bluefin tuna, Thunnus orientalis (Temminck \& Schlegel, 1844), cultured in Japan. Parasitol. Int. 60: 307-312.

Ogawa K., Tanaka S., Sugihara Y., Takami I. 2010: A new blood fluke of the genus Cardicola (Trematoda: Sanguinicolidae) from Pacific bluefin tuna, Thunnus orientalis (Temminck \& Schlegel, 1844) cultured in Japan. Parasitol. Int. 59: 44-48.

Overstreet R.M. 1983: Aspects of the biology of the spotted seatrout Cynoscion nebulosus, in Mississippi. Gulf Res. Rep., Supp. (June 1983) 1: 1-43.

Parukhin A.M. 1976: [New trematode species from fish in the southern Atlantic.] Biol. Morya 2: 28-30. (In Russian.)

Shirakashi S., Kishimoto Y., Kinami R., Katano H., Ishimaru K., Murata O., Itoh N., Ogawa K. 2012. Morphology and distribution of blood fluke eggs and associated pathology in the gills of cultured Pacific bluefin tuna, Thunnus orientalis. Parasitol. Int. 61: 242-249.

Sновт R.B. 1952: A new species of blood fluke from marine fish (Trematoda: Aporocotylidae). J. Parasitol. 38 (4, section 2): 36.

Short R.B. 1953: A new blood fluke, Cardicola laruei n. g., n. sp., (Aporocotylidae) from marine fishes. J. Parasitol. 39: 304-309.

Short R.B. 1954: A new blood fluke, Selachohemecus olsoni, n. g., n. sp. (Aporocotylidae) from the sharp-nosed shark, Scoliodon terra-novae. Proc. Helminthol. Soc. Wash. 21: 78-82.

Yamaguti S. 1970: Digenetic Trematodes of Hawaiian Fishes. Keigaku Publishing Company lt., Tokyo, 436 pp. 